\title{
MOBILE LEARNING WITH GAMIFICATION AND AUGMENTED REALITY IN PORTUGUESE HIGH EDUCATION
}

\author{
Fernando Moreira ${ }^{1,2,3}$, Natércia Durão ${ }^{1,2}$, Carla Santos Pereira ${ }^{1,2,5}$, Maria João \\ Ferreira $^{1,4}$ \\ ${ }^{1}$ Univ Portucalense, Research on Economics, Management and Information Technologies - \\ REMIT (PORTUGAL) \\ ${ }^{2}$ Univ Portucalense, Portucalense Institute for Legal Research - IJP (PORTUGAL) \\ ${ }^{3}$ IEETA, Universidade de Aveiro (PORTUGAL) \\ ${ }^{4}$ Centro Algoritmi, Universidade do Minho (PORTUGAL) \\ ${ }^{5}$ CEMAT, Universidade de Lisboa (PORTUGAL)
}

\begin{abstract}
The new technologies such as devices and mobile internet are becoming mainstream at a massive new scale. They are disrupting the ways organizations; namely higher education has operated for decades. Higher education schools must transform their teaching learning process and approaches to change how they engage with their students, innovate around new techniques and models and rethink how they operate. To lead in this digital era, higher education professors must use IT to enable students' intimacy at a massive scale, establish high-value in and out of the school. The future is promising for higher education transforming and overcome in this era. In this context is critical to understand whether users (students and professors) are receptive and aware to adapt to this new trends before deciding to implement teaching-learning approaches on mobile technology. The aim of this study is to investigate the perception if the Portuguese Universities professors using Mobile Learning with gamification and augmented reality and if so how they can be used to promote student's engagement inside and outside of the classroom.
\end{abstract}

Keywords: Mobile Learning, gamification, augmented reality, professors, Higher Education.

\section{INTRODUCTION}

Mobile or portable devices offer a wide range of opportunities, contributing to changes in the society where education is included. In this context, the evolution of new technologies in wireless communication systems as well as hardware and software for mobile devices has enabled the deployment of sophisticated communications and computing infrastructures to provide several mobile services.

According to Holzinger et al. [1] the organization of learning is changing with the introduction of technology in educational institutions, for example in learning activities. The same literature also point out that the correct use of most technologies stimulates the learning environments and promotes student motivation, being these important factors, determinants in learning. This is because attracting and motivating digital generation continues to create difficulties for educators around the world [2].

The intensive use of smart mobile devices and mobile applications has fuelled a new wave of demand for mobile services, namely mobile learning (m_learning), which introduces the ubiquitous wireless learning system. With the help of these systems, users (mostly students) of mobile devices can use the educational material in their device to learn. According to Ally [3] educational materials can be in the form of multimedia content or learning objects, which are characterized by interactivity, are very visual, engaging and effective leading to a better student learning. These learning objects can be easily used by students whenever needed and wherever they are, maximizing the "always there, always on" technology.

The capabilities of mobile devices have led to the emergence of technologies that have opened up new possibilities in the teaching and learning processes, namely Augmented Reality (AR) and Gamification.

AR allows users to view real environments in the real world with digital information overlapped in real environments (objects or locations), thus improving the user experience [4]. Three criteria for AR are defined in the literature [5]: (a) the combination of virtual and real environments, (b) real-time 
interaction and (c) 3D reference. The use of this technology with mobile devices gives students the opportunity to gain differentiated access to a particular topic to be studied. In this context, the AR mobilizes the learning environment regardless of location and time, allowing flexibility in learning, particularly in higher education.

Gamification is described as "using game-based mechanics, aesthetics and game thinking to engage people, motivate action, and promote learning." [2]. In a pedagogical context, O'Donovan [6] classified gamification as a didactic method, especially with respect to the validity of its integration. Gamification is not just a combination of elements of a game (points, leader boards, etc.), but should also be seen as an experience for the player [7]. In the context of the teaching-learning process, the use of gamification has had a positive result, particularly in the implementation in a set of themes and in several age groups, from undergraduate to university level [2].

In this context, the aim of this paper is to investigate the perception if the Portuguese Universities professors using Mobile Learning with gamification and augmented reality and if so how they can be used to promote student's engagement inside and outside of the classroom.

The paper is organized as follows. In section 2 the background of mobile learning as well as augmented realty and gamification is presented and discussed. The research methodology is presented in section 3 . In section 4 is presented the analysis and discussion of results. Finally, section 5 presents the final conclusions and some directions for future work.

\section{BACKGROUND}

\subsection{Mobile learning}

The concept of m_learning, according to [8] has received increasing attention from educational institutions regarding instructional environments. Such environments require careful assessment, both at the technical level and at the pedagogical level. Among the various definitions of $m$ learning, in [9] it is broadly defined as a form of e_learning that specifically uses mobile devices to provide learning and support content [10]. Essentially, $m_{-}$learning is based on the use of mobile devices anywhere at any time [11]. The predominant use of mobile technologies, also referred to as portable technologies, allows students to learn when and where they want [12]. These technologies also allow students to have access to learning content (e.g. learning materials, tests, dictionaries) and can benefit from a customized curriculum according to their learning needs [10].

The importance of perceptions, both by students [13], [14] and [15], and by professors [16] on the use of $m$ _learning applications has been focused and analyzed in different studies. These studies highlight the acceptance of mobile learning given the ease and capacity to use without time and location restrictions. However, it is necessary to look at several aspects of $m$ learning applications, namely the technical capacity of mobile devices, the expectations and capacities of students and professors, as well as the effectiveness of the tools in terms of the teaching-learning process.

In [17] a set of applications based on remote laboratory technology are presented and simultaneously identified as successful implementations that take advantage of m_learning, since they allow independent access to the laboratory location and are especially useful in scenarios where the space is limited or in the context of distance education [18]. Some of the most important examples are: MIT iLab, the Networked Control System Laboratory (NCSLab) and eComLab. In this context the literature shows that there are several types of m-learning applications, such as ubiquitous and augmented games [19] that use audio / video streaming and podcasting [20], aimed at different areas of study such as language learning [21], the teaching of the natural sciences [22], and that such applications have been developed according to the needs of the students and the characteristics of the different areas of knowledge.

\subsection{Augmented reality}

In the early 1990s Caudell and Mizell [23] introduced the term "Augmented Reality" (AR). In the early years, work in AR was limited to a small group of academics, later with the developments in smartphone technology became technologically possible to look through a mobile device and overlay virtual graphics in space, thus opening up new possibilities of its application in trade and industry [24] In these new applications it is possible to denote that augmented reality has become a tool used, for 
example, to aid medical procedures [25], to maintain and repair artefacts [26], to animate news [27], and to serve as a platform for providing advertising content [28].

As in almost all new technologies, finding a formally accepted definition across the community is often difficult. As far as AR is concerned, the issue is practically similar. In [29] a set of definitions is presented in chronological order: (i) in [30], an AR system complements the real world with virtual (computer generated) objects that seem to coexist in the same space as the real world. (ii) AR for Zhou et al. [31] is a technology that allows computer-generated virtual images to overlap exactly physical objects in real time. Unlike virtual reality (VR), where the user is completely immersed in a virtual environment, AR allows the user to interact with virtual images using real objects in a continuous way. (iii) Reitmayr and Drummond [32] define AR as a promising user interface technique for mobile and portable computing and location based systems. (iv) Carmigniani et al. [33] define AR as a direct or indirect real-time view of a real physical environment that has been augmented by adding computer generated virtual information to it.

Another relevant example of the application of RA, according to [34] is in the manufacturing industries that aim essentially to reduce product defects, cycle time and costs related to rework [35]. Thus, Michalos, et al. [34] showed that AR technologies allow users to view and interact with 3D objects more easily than they can through a simulation or computer screen, making them more appropriate for cases that: a) access to computers is not easy, and b) the time to seek and obtain assistance is limited [36]. Another application of AR, no less relevant, is in museum exhibitions. In this context, Nicola, et al. [37] showed that AR is adopted to emphasize real-world elements through computergenerated sensory inputs (sound, video, animations, etc.). In the same sense, the authors cite [38] as an example of the use of $A R$, for the reconstruction of 3D cultural objects, in museum exhibitions.

The application of AR in the context of the teaching-learning process is more complex, since it is not enough to build applications and use mobile devices for their use. Since the question must be raised: if augmented AR only affects the presentations of objects with the purpose of acting as a stimulus and improves the user's perception, or has some added value in an educational perspective? A possible answer to this question of education, according to [37] the "augmented" must be observed in two orthogonal perspectives: technological and cognitive, that is, the solution has to be integrative to not only become the introduction of more technology in the teaching-learning process in a single way, and that only introduces even more "noise".

\subsection{Gamification}

In 2011, Deterding et al. [38] defined gamification, such as the use of game design elements in nongame contexts; this area is relatively new but with rapid growth. However, its first use, documented, is 2008. This concept is different from the concept of an educational or serious game. However, the concept itself is not new, according to [2] the badges and rankings have long been used in the military in the Soviet era, where elements of the game were used by the leaders of the Soviet Union as a substitute for monetary reward in performing work, etc.

This concept is already being used in several areas, namely in business, marketing, corporate management, education / training and ecology [39]. The reason for their use advocated by these authors is justified by their potential to shape user behavior in a desirable direction. For example, you can highlight, among others, loyalty programs (frequent flyer, Foursquare and Nike + ). There are also other examples of organizations (Stackoverflow.com, codeacademy.com, khanacademy.org, eBay, Fitocracy, etc.) that took advantage of concepts such as reputation based on the number of right answers, how many more courses and lessons the users complete, more badges won, etc.

In the education and training sector, secondly [40] the principles of gamification, can contribute to help improve some or all aspects of education / training and are applied with "the intention to be more than entertainment" [41]. The main reason for this improvement is directly related to mechanisms that allow to increase the involvement with the learning contents and essentially to give feedback on the progress through the use of competitive tools such as rankings. Additionally, on the one hand, Connolly et al. [42] suggest that gamification may improve learning by overcoming some learning barriers, such as lack of attention, involvement and interest, introduced the pleasure factor in performing tasks, or learning activities [43]. On the other hand, the use of realistic and virtual simulations allows the understanding and internalization of concepts and be closer to reality [44]. 


\section{RESEARCH METHODOLOGY}

The purpose of this section is to describe the procedures used to collect data that are the basis for this research. The main feature of the scientific method is an organized research, strict control of the use of observations and theoretical knowledge.

For the present study, we used the methodology of quantitative research, since it is more appropriate to determine the opinions and attitudes of the respondent based on structured questionnaires. In this approach, data is collected through structured questionnaires, and clear goals in order to ensure uniform compression of the respondents and a consequent standardization of results.

The undertaken study was descriptive in nature. Data collected for quantitative research through the use of questionnaires requires special care because it is not enough to collect responses about the issues of interest, it is also important to know how to do statistical analysis for proper results validation. Aspects such as the sample size, the way the questionnaire is prepared, the questions formulation, data analysis, error margins, the selection of individual process of who should compose the sample, among other things, are important and they should be taken into account for any investigation [45]. This method is recommended when you want to know a population, to analyse social phenomena and, in cases where it is necessary to inquire a big number of people about a certain subject. The questionnaire before being delivered was subjected to the evaluation of four experts in the field.

The aim of this study is to investigate the perception of professors in higher education, the area of technology in Higher Education Institutions (HEls) in Portugal in relation to m-learning, and to identify the needs of professors as they relate to mobile technologies and how they can be used to promote student's engagement inside and outside of the classroom (augmented and gamification).

The quantitative study was based on an online questionnaire with several sections which include: Demographic information, Prior knowledge, Participation /Engagement, Use of Mobile Devices and Mobile use in the classroom. The first section (Demographic information) consists of 6 questions, which include, the age, gender and teach program(s). To achieve our goal, in the other sections we will only analyze the results regarding the issues related to $A R$ and Gamification in the MD (8 questions - Q1 to Q8). Almost all questions were close-ended type. Sections 3 and 5 use five-point Likert scale ranging from "Strongly Disagree" (1) to "Strongly Agree" (5). The questionnaire has been online for 60 days and 37 valid Portuguese responses were received. Data collected were pooled and treated by using the IBM SPSS Statistics 24.0 software. Statistical analyses used for the data analysis were frequency analysis, descriptive statistics, non-parametric tests (Chi-square, Fisher's test and Mann-Whitney) and Hierarchical Cluster Analysis.

\section{ANALYSIS AND DISCUSSION OF RESULTS}

The study sample consists of 37 professors from higher education in the area of technology in HEls in Portugal. Most respondent's gender were male $(64,9 \%)$ whereby, the majority of professors were aged between 41 to 50 years old $(59,5 \%)$. As for teach program, $73 \%$ of them teach in $\mathrm{PhD}, 78,4 \%$ in Master and $51,4 \%$ in Degree.

Since professors can simultaneously teach various levels of education, we find interesting to cross these data with the ages. It was concluded that, the youngest only teach in the under degree, and the higher the age group, the more levels of education they teach.

When it comes to the matter of "Prior Knowledge", we aim to assess whether the percentage of Portuguese higher education professors knows how to download augmented reality and gamification applications for MDs is significantly high (Table 1).

Table 1. Percentages of Yes and No responses for questions Q1 and Q2.

\begin{tabular}{llcr}
\hline Questions & No/Yes & (\%) \\
\hline \multirow{2}{*}{ Q1 Download augmented reality applications on a MD } & No & 29,7 \\
\hline & Yes & $\mathbf{7 0 , 3}$ \\
\hline \multirow{2}{*}{ Q2 Download Mobile App Gamification on a MD } & No & 29,7 \\
\hline
\end{tabular}


We note that the majority of Portuguese professors have knowledge on how to perform the downloaded augmented reality applications and download Mobile App Gamification on a MD despite being new technologies.

Next, we check if the gender of professors is independent of whether they know-how to download augmented reality and gamification applications for MDs (Tables 2-3). Note that the cross tables constructed to perform the Chi-square test are $2 \times 2$ tables, which showed that they had more than $20 \%$ of the cells with expected frequencies below 5 (one of the conditions of applicability of the test). This is the reason why we had to opt for Fisher's Test $(p$-value $=0.006<0.05$ and $p$-value $=0.143>0.05$, respectively) [46, 47].

Firstly, we can conclude that there is an association between gender and the download of augmented reality applications for MDs, which can be confirmed by carefully analyzing Table 2, since it is well known that for female "No" predominates (61.5\%), and for males the "Yes" predominates $(87.5 \%)$.

In contrast, there is no statistically significant association between the gender and the download of gamification applications to MDs. This fact is confirmed in Table 3, when we find that the "Yes" predominates regardless of the gender of the professor $(79.2 \%$ - male, $53.8 \%$ - female).

Table 2. Frequencies for question $\mathrm{Q} 1$ by gender.

\begin{tabular}{lcccc}
\hline Question & & Male & Female & Total \\
\hline \multirow{2}{*}{ Q1 } & No & 3 & 8 & 11 \\
\cline { 3 - 4 } & & $27,3 \%$ & $72,7 \%$ & $100,0 \%$ \\
\cline { 2 - 4 } & & $12,5 \%$ & $\mathbf{6 1 , 5 \%}$ & $29,7 \%$ \\
\cline { 2 - 4 } & Yes & 21 & 5 & 26 \\
\cline { 2 - 4 } & & $80,8 \%$ & $19,2 \%$ & $100,0 \%$ \\
\cline { 2 - 4 } & & $\mathbf{8 7 , 5 \%}$ & $38,5 \%$ & $70,3 \%$ \\
\hline \multirow{2}{*}{ Total } & 24 & 13 & 37 \\
& & $64,9 \%$ & $35,1 \%$ & $100,0 \%$ \\
\hline & & $100,0 \%$ & $100,0 \%$ & $100,0 \%$ \\
\hline
\end{tabular}

Table 3. Frequencies for question $Q 2$ by gender.

\begin{tabular}{lcccc}
\hline Question & & Male & Female & Total \\
\hline \multirow{2}{*}{ Q2 } & No & 5 & 6 & 11 \\
\cline { 3 - 4 } & & $45,5 \%$ & $54,5 \%$ & $100,0 \%$ \\
\cline { 2 - 4 } & & $20,8 \%$ & $46,2 \%$ & $29,7 \%$ \\
\cline { 2 - 4 } & Yes & 19 & 7 & 26 \\
\cline { 2 - 4 } & & $73,1 \%$ & $26,9 \%$ & $100,0 \%$ \\
\cline { 2 - 4 } & & $\mathbf{7 9 , 2} \%$ & $\mathbf{5 3 , 8 \%}$ & $70,3 \%$ \\
\hline Total & 24 & 13 & 37 \\
\cline { 2 - 4 } & & $64,9 \%$ & $35,1 \%$ & $100,0 \%$ \\
\hline & & $100,0 \%$ & $100,0 \%$ & $100,0 \%$ \\
\hline
\end{tabular}

It is also of interest to note that there is an association between Q2 and the fact that the professor teaches or not doctoral courses (Fisher's test with p-value $=0.013<0.05$ ). This is because, while most of those who teach these courses $(89.5 \%)$ know how to download mobile gamification apps on a MDs, compared to those who do not teach these courses only $50 \%$ know how to download.

As can be seen in Table 4, in terms of Participation/Engagement, both mean values are above the neutral position of 3 which suggested that professors agree that augmented reality and gamification could be incorporated into ML class. 
Table 4. Descriptive Statistics for questions Q3 and Q4.

\begin{tabular}{lrr}
\hline Questions & Mean & Std. Deviation \\
\hline Q3 - Augmented reality could be incorporated into ML classes & 4,00 & 1,080 \\
\hline Q4 - Gamification could be incorporated into ML classes & 4,08 & 1,010 \\
\hline
\end{tabular}

As questions Q3 and Q4 are measured on an ordinal scale, in order to assess whether there are differences in professors' opinions, to incorporate into the classrooms, augmented reality and gamification according to gender, we performed the Mann-Whitney statistical test ( $p$-value $=0.404>$ 0.05 and $p$-value $=0.814>0.05$ respectively). Although these results lead us to conclude that there are no statistically significant differences, the separate calculation by gender of the means reveals that in relation to Q3, male professors tend to be less inclined to incorporate augmented reality applications in classrooms (Male: mean $=3.92$; Female: mean $=4.15$ ).

In regard to "Use of Mobile Devices" to perform educational tasks, inside or outside the class, we conclude that most professors agree that students play an educational game on their MD (Q5) and use MD with augmented reality (Q6) as a learning tool (Table 5).

Table 5. Percentages of Yes and No responses for questions Q5 and Q6.

\begin{tabular}{|c|c|c|c|}
\hline Questions & & No/Yes & $(\%)$ \\
\hline \multirow{2}{*}{ Q5 } & \multirow{2}{*}{ Students play an educational game on MD } & No & 43,2 \\
\hline & & Yes & 56,8 \\
\hline \multirow{2}{*}{ Q6 } & \multirow{2}{*}{ Students use MD with augmented reality as a learning tool } & No & 48,6 \\
\hline & & Yes & 51,4 \\
\hline
\end{tabular}

For these two questions, after crossing with gender, given the resulting tables (Tables 6-7), we are led to believe that there is an association between gender and questions Q5 and Q6. This is because $66.7 \% / 58.3 \%$ of male professors agree with the use of gamification and augmented reality in their $\mathrm{MD}$ as a learning tool, respectively. Here, as all Chi-square test conditions of applicability are verified, it was used (with continuity correction $-2 \times 2$ tables) to evaluate this possible association. However, the values obtained for these tests contradict our assumption ( $p$-value $=0.192>0.05$ and $p$-value $=$ $0.418>0.05)$, that is, statistically we cannot state that exist the association between the gender and $\mathrm{Q} 5$ and $\mathrm{Q6}$ variables.

Table 6. Frequencies for question Q5 by gender.

\begin{tabular}{lcccc}
\hline Question & & Male & Female & Total \\
\hline \multirow{2}{*}{ Q5 } & No & 8 & 8 & 16 \\
\cline { 3 - 4 } & & $50,0 \%$ & $50,0 \%$ & $100,0 \%$ \\
\cline { 2 - 4 } & & $33,3 \%$ & $61,5 \%$ & $43,2 \%$ \\
\cline { 2 - 4 } & \multirow{2}{*}{ Yes } & 16 & 5 & 21 \\
\cline { 3 - 4 } & & $76,2 \%$ & $23,8 \%$ & $100,0 \%$ \\
\cline { 2 - 4 } & & $\mathbf{6 6 , 7 \%}$ & $\mathbf{3 8 , 5 \%}$ & $56,8 \%$ \\
\hline \multirow{2}{*}{ Total } & 24 & 13 & 37 \\
\cline { 2 - 4 } & & $64,9 \%$ & $35,1 \%$ & $100,0 \%$ \\
\hline & & $100,0 \%$ & $100,0 \%$ & $100,0 \%$ \\
\hline
\end{tabular}


Table 7. Frequencies for question Q6 by gender.

\begin{tabular}{lcccc}
\hline Question & & Male & Female & Total \\
\hline \multirow{2}{*}{ Q6 } & No & 10 & 8 & 18 \\
\cline { 3 - 4 } & & $55,6 \%$ & $44,4 \%$ & $100,0 \%$ \\
\cline { 2 - 4 } & & $41,7 \%$ & $61,5 \%$ & $48,6 \%$ \\
\cline { 2 - 4 } & Yes & 14 & 5 & 19 \\
\cline { 3 - 4 } & & $73,7 \%$ & $26,3 \%$ & $100,0 \%$ \\
\cline { 2 - 4 } & & $\mathbf{5 8 , 3} \%$ & $\mathbf{3 8 , 5 \%}$ & $51,4 \%$ \\
\hline \multirow{2}{*}{ Total } & $\mathbf{2 4}$ & 13 & 37 \\
\cline { 2 - 4 } & & $64,9 \%$ & $35,1 \%$ & $100,0 \%$ \\
\hline & & $100,0 \%$ & $100,0 \%$ & $100,0 \%$ \\
\hline
\end{tabular}

It should be noted that, whatever the degree taught by professors, we found that as far as students play educational game on their MD, they predominantly agree with the use of this educational tool (with percentages of "Yes" above 60\%). For students who use their MDs with augmented reality applications as a learning tool, professors' opinions, regardless of the degree they teach, are no longer predominantly in favour, since both percentages ("Yes" and "No" ) are in the order of $50 \%$.

As can be seen in Table 8, in terms of mobile use in the classroom, both mean values are quite above the neutral position of 3 which suggested that professors believe that students can appropriately use MD with augmented reality apps (Q7) and with gamification apps (Q8), for learning.

Table 8. Descriptive Statistics for questions Q7 and Q8.

\begin{tabular}{lrr}
\hline Questions & Mean & Std. Deviation \\
\hline Q7 - MD with augmented reality apps for learning & 4,05 & 0,941 \\
\hline Q8 - MD with gamification apps for learning & 4,05 & 0,941 \\
\hline
\end{tabular}

In order to evaluate whether gender influences the professors' opinions regarding Q7 and Q8 questions given the measurement scales of the variables are ordinal, we performed the Mann-Whitney statistical test ( $p$-value $=0.913>0.05$ and $p$-value $=0.582>0.05$, respectively). Although these results lead us to conclude that there are no statistically significant differences, the separate calculation by gender of the means reveals that for both questions the male professors have a lower tendency to believe that students can be taught how to appropriately use MD with augmented reality apps and with gamification apps, for learning (male: mean $=4.00$ / 3.96; female: mean $=4.15 / 4.23$ for questions Q7 and Q8, respectively).

Finally, in order to group the variables into homogeneous groups, we use Hierarchical Cluster Analysis (exploratory multivariate data analysis) [47] where each variable belonging to a given cluster is similar to all others belonging to that cluster and is different from the variables belonging to other clusters.

According to the dendogram obtained (Figure 1), the variables Q7 ("Professors believe that students can be taught how to appropriately use MD with augmented reality apps for learning") and Q8 ("Professors believe that students can be taught how to appropriately use MD with gamification apps for learning") are very close (strongly correlated) and Q3 ("Augmented reality could be incorporated into mobile learning classes") and Q4 ("Gamification could be incorporated into mobile learning classes") are associated with these a slightly greater distance forming a cluster. The other variables are associated successively (at a greater distance). The variable Q6 ("Professors agree with students use their MD with augmented reality as a learning tool, inside or outside the class") is the most dissimilar of the others. 


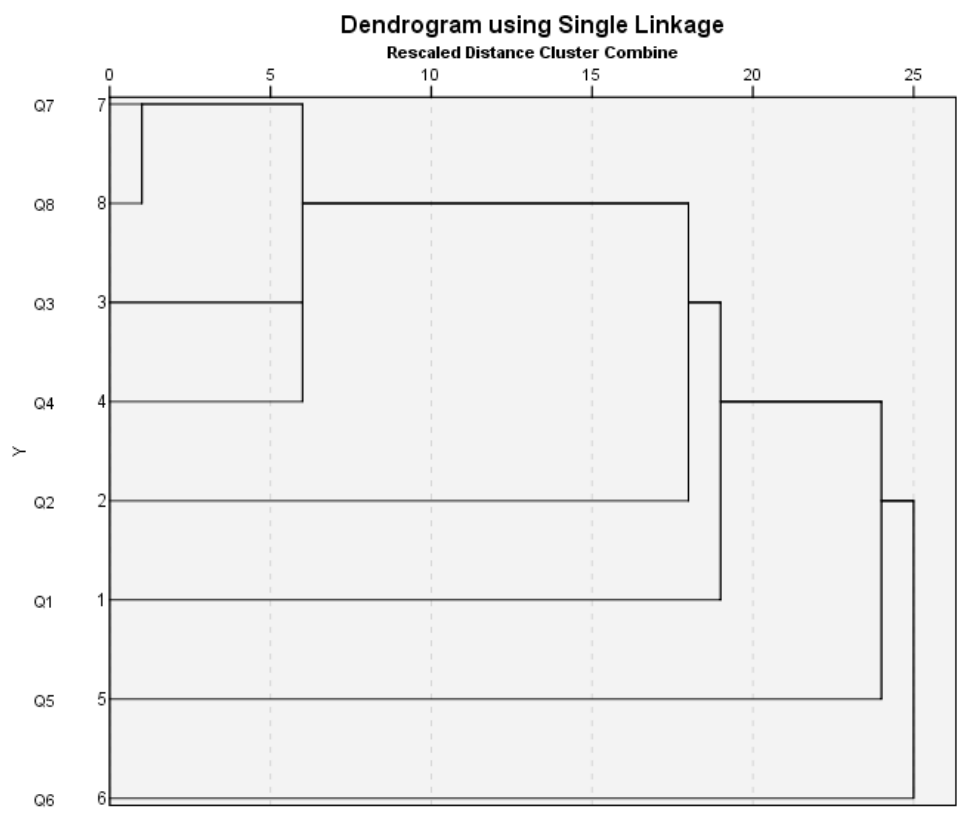

Figure 1. Dendogram for questions Q1 to Q8.

\section{CONCLUSIONS AND FUTURE WORK}

The new technologies such as devices and mobile internet are becoming mainstream at a massive new scale. Higher education institutions must transform their teaching learning process and approaches to change how they engage with their students, innovate around new techniques and models and re-think how they operate. The use of new approaches like AR and/or Gamification must be a reality at this moment. In this context, High Education is required to address the present needs, i.e., to create learning options that involve and encourage the actual students - a community highly digital.

In this study, we focused on analysing the introduction of AR and Gamification in m_learning in the teaching learning process in high education in Portugal.

In the obtained results it is possible to emphasize that the professors already had a very strong previous knowledge regarding the capacity to install applications of augmented reality, and gamification. However, one of the interesting results obtained is that women have less know-how for the technologies but more willingness to incorporate them into their classrooms. On the other hand, the participation and the engagement to incorporate these two technologies in the classroom is seen by the professors as very positive, therefore, are met the essential conditions for their adoption in the teaching-learning process. To complement this trend, when professors are questioned about their beliefs regarding the added value of using these technologies (augmented reality apps and gamification apps), the results obtained are very positive.

As future work, it would be interesting to continue our research from the student's point of view, and the reality concerning other countries.

\section{REFERENCES}

[1] A. Holzinger, A. Nischelwitzer, M. Meisenberger, "Lifelong-learning support by m-learning: example scenarios," eLearn, vol. 11, no. 2, 2005, http://dx.doi.org/10.1145/1125280.1125284

[2] K. Kapp, "The Gamification of Learning and Instruction: Game-Based Methods and Strategies for Training and Education," John Wiley \& Sons, 2012.

[3] M. Ally, "Mobile learning: transforming the delivery of education and training," 2009, http://books.google.com/books?hl=en\&lr=\&id=Itp60WteuJsC\&oi=fnd\&pg=PR1\&dq=Mobile+Lear ning+Transforming+the+Delivery+of+Education+and+Training\&ots=5XKSJ3HRjk\&sig=PK7UEp d4 Leuzx9XrO5-wj8pzkl 
[4] D. Berryman, "Augmented reality: A Review," Medical Reference Services Quarterly, vol. 31, no. 2, pp. 212-218, 2012.

[5] R. Azuma, "A Survey of augmented reality," Presence, vol. 6, no. 4, pp. 355-385, 1997.

[6] S. O'Donovan, J. Gain, P. Marais, "A Case Study in the Gamification of a University-level Games Development Course," In Proceedings of the South African Institute for Computer Scientists and Information Technologists Conference, pp. 242-251, 2013, http://dx.doi.org/10.1145/2513456.2513469

[7] K. Werbach, D. Hunter, "For the win: How game thinking can revolutionize your business," Wharton Digital Press, 2012.

[8] Ö. Delialioğlu, Y. Alioon, "The effect of students' subject discipline on their m-learning application preferences," Interactive Learning Environments, vol. 24, no. 8, pp. 1957-1966, 2016.

[9] Y.-M. Cheng, "Towards an understanding of the factors affecting m-learning acceptance: Roles of technological characteristics and compatibility", Asia Pacific Management Review, no. 20, pp 109-119, 2015.

[10] G.-J. Hwang, H.-F. Chang, "A formative assessment-based mobile learning approach to improving the learning attitudes and achievements of students," Computers and Education, vol. 56, no. 4, pp. 1023-1031, 2011.

[11] C.-C. Chen, T.-C. Huang, "Learning in a u-Museum: developing a contextaware ubiquitous learning environment," Computers and Education, vol. 59, no. 3, pp. 873-883, 2012.

[12] C. Evans, "The effectiveness of $m$-learning in the form of podcast revision lectures in higher education," Computers and Education, vol. 50, no. 2, pp. 491-498, 2008.

[13] K. Jairak, P. Praneetpolgrang, K. Mekhabunchakij, "An acceptance of mobile learning for higher education students in Thailand," The Sixth International Conference on elearning for Knowledge-Based Society, Bangkok, Thailand, 2009.

[14] S. S.Liaw, M. Hatala, H. M. Huang, "Investigating acceptance toward mobile learning to assist individual knowledge management: Based on activity theory approach," Computer \& Education, no. 54 , pp. 446-454, 2010.

[15] F. Moreira, M. J. Ferreira, C. Santos Pereira, N. Durão, "Evolution and use of mobile devices in higher education: A case study in Portuguese Higher Education Institutions between 2009/10 and 2014/15," Telematics and Informatics Journal. (2016). http://dx.doi.org/10.1016/j.tele.2016.08.010

[16] F. Moreira, M. J. Ferreira, C. Santos Pereira, N. Durão, "Mobile Learning In Portuguese Universities: Are Professors Ready?," Advances in Intelligent Systems and Computing series, 2017, accept for publication.

[17] N. Wang, X. Chen, G. Song, Q. Lan, H. Parsaei, "Design of a New Mobile-Optimized Remote Laboratory Application Architecture for M-Learning," IEEE Transactions on Industrial Electronics, vol. 64, no. 3, pp. 2382 - 2391, 2017.

[18] A. A. Kist, P. Gibbings, A. D. Maxwell, H. Jolly, "Supporting remote laboratory activities at an institutional level," Int. J. Online Eng., vol. 9, no. S5, pp. 38-47, 2013.

[19] F. Fotouhi-Ghazvini, R. A. Earnshaw, D. Robinson, P. S. Excell, "Designing augmented reality games for mobile learning using an instructional-motivational paradigm," International Conference on Cyber World, Bradford, UK:, 2009.

[20] K. Mandula, S. R. Meda, D. K. Jain, "Research and implementation of a mobile video streaming application for ubiquitous learning," IEEE International Conference on Technology Enhanced Education, Kerala, India, 2012.

[21] N. A. Gromik, "Cell phone video recording feature as a language learning tool: A case study," Computer \& Education, no. 58, pp. 223-230, 2012.

[22] G. J Hwang, P. H. Wu, H. R. Ke, "An interactive concept map approach to supporting mobile learning activities for natural science courses," Computer \& Education, no. 57, pp. 2272-2280, 2011. 
[23] T. Caudell, D. Mizell, "Augmented reality: An application of heads-up display technology to manual manufacturing processes," In Proceedings of the Twenty-fifth Hawaii International Conference on, no. 2, pp. 659-669, 1992.

[24] T. Liao, "Is it 'augmented reality'? Contesting boundary work over the definitions and organizing visions for an emerging technology across field-configuring events," Information and Organization, no. 26, pp. 45-62, 2016.

[25] T. Sielhorst, M. Feuerstein, N. Navab, "Advanced medical displays: A literature review of augmented reality," Journal of Display Technology, vol. 4, no. 4, pp. 451-467, 2008.

[26] S. Henderson, S. Feiner, "Evaluating the benefits of augmented reality for task localization in maintenance of an armored personnel carrier turret. Mixed and augmented reality," 8th IEEE International Symposium on ISMAR, pp. 135-144, 2009.

[27] J. Pavlik, F. Bridges, "The emergence of augmented reality (AR) as a storytelling medium in journalism," Journalism \& Communication Monographs, vol. 15, no. 1, pp. 4-59, 2013.

[28] T. Liao, "Augmented or admented reality? The influence of marketing on augmented reality technologies," Information, Communication \& Society, vol. 18, no. 3, pp. 310-326, 2015.

[29] A. Javornik, "Augmented reality: Research agenda for studying the impact of its media characteristics on consumer behavior," Journal of Retailing and Consumer Services, no. 30, pp. 252-261, 2016.

[30] R. Azuma, R. Behringer, S. Julier, B. Macintyre, "Recent advances in augmented reality," IEEE Comput. Graph. Appl, no. 21, pp. 34-47, 2001.

[31] F. Zhou, H. Duh, M. Billinghurst, M., "Trends in augmented reality tracking, interaction and display: A review of ten years of ISMAR," In Proceedings of the 2008 7th IEEE/ACM International Symposium on Mixed and Augmented Reality, pp. 193-202, 2008.

[32] G. Reitmayr, T. Drummond, "Going out: robust model-based tracking for outdoor augmented reality," In Proceedings of the 2006 IEEE/ACM International Symposium on Mixed and Augmented Realilty, pp. 109-118, 2006.

[33] J. Carmigniani, B. Furht, M. Anisetti, P. Ceravolo, E. Damiani, M. Ivkovic, "Augmented reality technologies, systems and applications," Multimed. Tools Appl, no. 51, pp. 341-377, 2011.

[34] G. Michalos, P. Karagiannis, S. Makris, Ö. Tokçalar, G. Chryssolouris, "Augmented reality (AR) applications for supporting human-robot interactive cooperation," Procedia CIRP, no. 41, pp. $370-375,2016$.

[35] G. Chryssolouris. "Manufacturing Systems: Theory and Practice," 2nd ed. New York: SpringerVerlag; 2006.

[36] G. Chryssolouris, D. Mavrikios, N. Papakostas, D. Mourtzis, "Education in Manufacturing Technology \& Science: A view on Future Challenges \& Goals", Inaugural Keynote, (ICMAST) International Conference on Manufacturing Science and Technology, Melaka, Malaysia, 2006.

[37] N. Capuano, A. Gaeta, G. Guarino, S. Miranda, S. Tomasiello, "Enhancing augmented reality with cognitive and knowledge perspective: a case study in museum exhibitions," Behaviour \& Information Technology, vol. 35, no. 11, pp. 968-979, 2016.

[38] S. Deterding, D. Dixon, R. Khaled, L. Nacke, (2011). From game design elements to gamefulness: Defining "gamification." In A. Lugmayr, H. Franssila, C. Safran, \& I. Hammouda (Eds.), MindTrek, pp. 9-15, 2011.

[39] D. Dicheva, C. Dichev, G. Agre G. Angelova, "Gamification in Education: A Systematic Mapping Study," Educational Technology \& Society, vol. 18, no. 3, pp. 75-88, 2015.

[40] R. J. Baxter, D. Kip Holderness, D. A. Wood, "Applying Basic Gamification Techniques to IT Compliance Training: Evidence from the Lab and Field", Journal of Information Systems, vol. 30, no. 3, pp. 119-133, 2016.

[41] U. Ritterfield, M. Cody, P. Vorderer, "Serious Games: Mechanisms and Effects," London, U.K.: Routledge, 2009. 
[42] T. M. Connolly, E. A. Boyle, E. MacArthur, T. Hainey, J. M. Boyle, "A systematic literature review of empirical evidence on computer games and serious games," Computers \& Education, vol. 59, no. 2, pp. 661-686, 2012.

[43] M. Ainley, J. Ainley, "A cultural perspective on the structure of student interest in science," International Journal of Science Education, vol. 33, no. 1, pp. 51-71, 2011.

[44] J. Hamari, J. Koivisto, H. Sarsa, "Does Gamification Work?-A Literature Review of Empirical Studies on Gamification," 2014, http://ieeexplore.ieee.org/stamp/stamp.jsp?arnumber1/46758978

[45] L-V Campenhoudt, R. Quivy, "Manual de Investigação em Ciências Sociais," Gradiva Publicações, 2008.

[46] M. H. Pestana, J. N. Gageiro, "Análise de dados para Ciências Sociais. A complementaridade do SPSS," (6 ${ }^{a}$ edição) Lisboa: Edições Sílabo, 2014.

[47] J. Maroco, "Análise Estatística com o SPSS," (6 edição). ReportNumber, Lda, 2014. 